Creative commons User License: CC BY-NC-ND

Abstracted by: EBSCOhost, Electronic Journals Service (EJS),

Google Scholar, Directory of Open Access Journals (DOAJ),

Journal Seek, Scientific Commons,

Food and Agricultural Organization (FAO), CABI and Scopus
Journal of Agricultural Extension

Vol. XX (X) XXXXXX, 20XX

ISSN(e): 24086851; ISSN(Print); 1119944X

http://journal.aesonnigeria.org

http://www.ajol.info/index.php/jae

Email: editorinchief@aesonnigeria.org

\title{
Attitude of Women Cassava Farmers Towards Participation in Growth Enhancement Support Scheme in Oyo state, Nigeria
}

http://dx.doi.org/10.4314/jae.v20i2.7

\section{Tijani, Sarafat. Ayanfunke.}

Department of Agricultural Extension and Rural Development, Faculty of Agriculture and Forestry University of Ibadan, Ibadan tsarafat@yahoo.com; Phone: +234-08051370802

\section{Umoh, Imoh Edet}

Department of Agricultural Extension and Rural Development, Faculty of Agriculture and Forestry University of Ibadan, Ibadan. Phone +234- 08031303963 richncute3@gmail.com

\section{Abstract}

The study examined attitude of women cassava farmers towards the Growth Enhancement Support Scheme (GESS) in Oyo state. Three LGAs were purposively selected while random sampling was used to select 4 communities in each LGA with five respondents each using snowball method to give sample size of 180 respondents. Interview schedule was used for data collection and analysed using descriptive and inferential statistics. Results reveal that most of the respondents (67.8\%) were within 31-50years of age, married $(90.0 \%)$, literate $(57.8 \%)$ with open market $(\bar{x}=1.98)$ and middlemen $(\bar{x}=1.78)$ being the preferred sources of inputs. More than half $(52.7 \%)$ had over ten years of farming experience, 52.3\% cultivated above 6 acres, $68.3 \%$ had high level of participation in GESS while 63.3 had favourable attitude towards GESS. Inadequate finance $(\bar{x}=1.94)$ and high illiteracy $(\bar{x}=1.93$ were the constraints to participation. Significant relationship exists between education $\left(X^{2}=2.315, p=0.040\right)$, level of participation $(r=0.258, p=0.000)$, sources of input ( $r=0.223, p=0.003)$, constraint to participation ( $r=0.424$, $p=0.000$ ) and attitude towards GESS. Though, many respondents were unable to access agricultural inputs from redemption centers yet they had favourable attitude towards GESS. Proper inputs distribution mechanism to eliminate diversion and financial institution with minimum interest rate and collateral should be employed.

Keywords: Growth enhancement support scheme, women cassava farmers, participation 
Creative commons User License: CC BY-NC-ND

Abstracted by: EBSCOhost, Electronic Journals Service (EJS),

Google Scholar, Directory of Open Access Journals (DOAJ),

Journal Seek, Scientific Commons,

Food and Agricultural Organization (FAO), CABI and Scopus
Journal of Agricultural Extension

Vol. XX (X) XXXXXX, 20XX

ISSN(e): 24086851; ISSN(Print); 1119944X

http://journal.aesonnigeria.org

http://www.ajol.info/index.php/jae

Email: editorinchief@aesonnigeria.org

\section{Introduction}

Agriculture is an important sector of the economy with high potentials for employment generation, food security and poverty reduction. It is argued that women account for $70-80 \%$ of household food production in sub-Sahara Africa. Women farmers grow more than half of all the food in developing countries and up to $80 \%$ in parts of Africa, generally in the form of small-scale crops for household consumption (Obiora, 2013). In the agricultural sector of the country, women play a vital role from direct production to value addition (in terms of processing and storage) and in marketing of agricultural produce (Ogbonna and Okoroafor, 2004). Agriculture has not fulfilled its potential, suffering from a lack of investment to insufficient attention by policy makers. One of the key hindrances to agricultural development as noted by World Bank (2014) is the wide and pervasive gender gap in agricultural productivity. Food development programmes are often focused in the designing of effective packages for the production of surpluses in agriculture without any particular focus on the women, (Ogbonna and Okoroafor, 2004); hence, the need to restructure the sector to achieve its potentials.

In the bid to achieve the above goal, the Federal Government of Nigeria initiated the Agricultural Transformation Agenda (ATA) in 2011 to boost local food production thereby unlocking the country's huge agricultural potentials. The government sees its agriculture transformation agenda (ATA) as a critical tool for driving rural income growth, accelerating the achievement of food and nutritional security, generating employment, and transforming the country into a leading player in global food markets (Porter, Raewyn, Zouighian and Daine, 2014). The ATA sets out to create over 3.5 million jobs along the value chains of the priority crops such as rice, sorghum, cassava, horticulture, cotton, cocoa, oil palm, etc. for Nigeria's teeming youths and women, in particular (Feeral Ministry of Agriculture and Rural development (Federal Ministry of Agriculture and Rural Development, (FMARD) 2013).

Cassava is one of the priority crops promoted by ATA of which Nigeria happens to be the World largest producer and has the most advanced cassava transformation in 
Creative commons User License: CC BY-NC-ND

Abstracted by: EBSCOhost, Electronic Journals Service (EJS),

Google Scholar, Directory of Open Access Journals (DOAJ),

Journal Seek, Scientific Commons,

Food and Agricultural Organization (FAO), CABI and Scopus
Journal of Agricultural Extension

Vol. XX (X) XXXXXX, 20XX

ISSN(e): 24086851; ISSN(Print); 1119944X

http://journal.aesonnigeria.org

http://www.ajol.info/index.php/jae

Email: editorinchief@aesonnigeria.org

Africa. Literature has it that cassava is cultivated by over 30 million farmers in the country, with an estimate produce of about 37.5 million tonnes harvested in 2010 (FAO 2012). Cassava is considered a God-given crop against acute food insecurity (Koyenikan and Edeoghon, 2010) and tolerant to low soil fertility, drought, most pests and diseases with no critical date of harvest and can thrive on marginal soils where other crops fail.

The ATA was designed to cover all farmers throughout the federation among which are women farmers, with $60 \%$ of all agricultural funding set aside for women farmers. This bias towards women farmers is encouraging since they typically have lower output per unit land and are much less likely to be active in commercial farming due to gender differences in access to resources and services. Among the components of ATA is the Growth Enhancement Support Scheme (GESS) - designed to enhance agricultural productivity through timely, efficient and effective delivery of yieldincreasing farm inputs such as improved seeds and fertilizers. ATA is known as Greenhouse in Oyo state. Women cassava farmers are directly under the GESS programme.

Various researches conducted on the contribution of women to agricultural development in the country suggest that women's contribution to farm work is as high as between 60 and $90 \%$ of the total farm task performed. Despite their contributions, women are often excluded from certain occupational categories due to gender imbalance created by formal as well as informal barriers to entry. The formal barriers which continue to hinder the entry of women into such occupational categories include: lack of educational or technical training, labour laws and trading customs; while the informal barriers include: customs and religious practices, difficulties in combining domestic and labour market activities, and management and worker attitudes (Lawanson, 2008).

Women rarely own land in Nigeria despite their heavy involvement in agriculture as land tenure system is largely by inheritance. This lack of title to land prevents women from exercising or improving their expertise in crop production and animal husbandry because of security of tenure. Also, the majority of them use low yielding and 
Creative commons User License: CC BY-NC-ND

Abstracted by: EBSCOhost, Electronic Journals Service (EJS),

Google Scholar, Directory of Open Access Journals (DOAJ),

Journal Seek, Scientific Commons,

Food and Agricultural Organization (FAO), CABI and Scopus
Journal of Agricultural Extension

Vol. XX (X) XXXXXX, 20XX

ISSN(e): 24086851; ISSN(Print); 1119944X

http://journal.aesonnigeria.org

http://www.ajol.info/index.php/jae

Email: editorinchief@aesonnigeria.org

unimproved planting materials, primitive and labour intensive farm implements, and traditional farming practices which have adversely affected agricultural production. It has been reported that $80 \%$ of the work done on the farm in agricultural activities take place in rural areas. It is also widely demonstrated that rural women, as well as men, throughout the world are engaged in a range of productive activities essential to household welfare, agricultural productivity and economic growth. Yet women's substantial contribution continues to be under-valued in conventional agricultural and economic analyses and policies, while men's contribution remains the central, often, the sole focus of attention (Fabiyi, Danladi, Akande, and Mahmood, 2007).

Since the commencement of ATA, the attitude of women cassava farmers towards their participation in the Growth Enhancement Support Scheme has not been ascertained. The specific objectives were to:

1. describe the personal characteristics of women cassava farmers;

2. identify the sources of information about GESS available to women cassava farmers;

3. identify the sources through which women cassava farmers acquire their inputs;

4. determine the attitude of women cassava farmers towards GESS;

5. determine the level of participation of women cassava farmer in GESS; and

6. identify the constraints to participation of women cassava farmers in GESS.

\section{Methodology}

The study was carried out in Oyo state, one of the six states in Southwest, Nigeria. It is geographically located within Latitudes $5^{0} 15 \mathrm{~N}$ and $9^{0} 10 \mathrm{~N}$, and Longitudes $2^{0} 50 \mathrm{E}$. The state, which covers an area of approximately $32,241.8$ square kilometers, is made up of thirty-three (33) local government areas with a population of 5,591,589 (National Population Commission, (NPC) 2006). The vegetation is dictated by the rainfall pattern of about $130 \mathrm{~mm}$ to $150 \mathrm{~mm}$ per annum, and ranges from rain forest to derived savannah. The climate is equatorial with notable dry and wet seasons with high relative humidity. The dry season is between November and March, while the 
Creative commons User License: CC BY-NC-ND

Abstracted by: EBSCOhost, Electronic Journals Service (EJS),

Google Scholar, Directory of Open Access Journals (DOAJ),

Journal Seek, Scientific Commons,

Food and Agricultural Organization (FAO), CABI and Scopus
Journal of Agricultural Extension

Vol. XX (X) XXXXXX, 20XX

ISSN(e): 24086851; ISSN(Print); 1119944X

http://journal.aesonnigeria.org

http://www.ajol.info/index.php/jae

Email: editorinchief@aesonnigeria.org

wet season is between April and October. The target population of the study included women cassava farmers in the state. Multistage sampling was used to select respondents for the study. The first stage involved purposive selection of 3 LGAs from the 33 LGAs in the state based on their involvement in GESS. Simple random sampling was used to select 4 wards from the 10 wards in each selected LGA. Three communities were purposively selected from each of the 4 wards based on their involvement in cassava production. Snowball sampling technique was then used to select five respondents each from the selected communities to give a total of 180 respondents. Data was collected using interview schedules. Information and Input source were measured using: always $=2$, occasionally $=1$ and never $=0$. Mean for each source was computed and ranked based on the highest. Participation in GESS was measured with always $=2$, occasionally $=1$ and never $=0$. Mean was generated from the responses and used to categorise respondents' level of participation into high and low. Constraints to participation in GESS was done using serious $=2$, mild $=1$ and not a constraint $=0$. Mean was also used to rank the constriants according to severity. Attitude towards GESS was measured using Likert type scale of strogly agree $(A)=5$, agree $(A)=4$, undecided $(U)=3$, disagree $(D)=2$, strongly disagree $(S D)=1$ for positively- worded statements and vice versa for negatively-worded statements. Mean was computed from the aggregated scores and this formed the basis for classification of women cassava farmers' attitude into favourable and unfavourable

\section{Results and Discussion}

\section{Personal characteristics of respondents}

The age distribution of the respondents showed that the majority (67.8\%) fell within the age range of $31-50$ years $(\bar{x}=42$ years). This tells one that the majority of the women cassava farmers falls in the middle age category and would be actively involved in farming activities aimed at improving their livelihood. People within this age range constitutes the active work force and tend to make vital impact in agricultural production, processing and technological development (Akinbile, 2007; Enitan, 2010). The majority $(90.0 \%)$ of them were married, with $76.7 \%$ having 
Creative commons User License: CC BY-NC-ND

Abstracted by: EBSCOhost, Electronic Journals Service (EJS), Google Scholar, Directory of Open Access Journals (DOAJ), Journal Seek, Scientific Commons,

Food and Agricultural Organization (FAO), CABI and Scopus

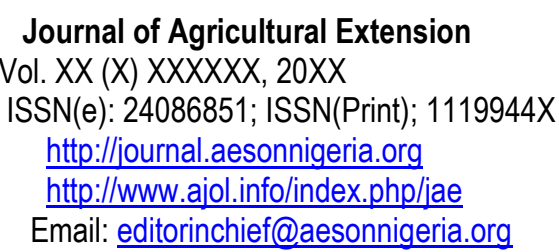

household sizes of $4-6$ individuals. Hence they engaged in agriculture in order to cater for family needs since marriage, confers responsibilities. Meanwhile, their family members can serve as a source of farm labour. It was revealed that $57.8 \%$ had one form of formal education or the other, which should translate to a better understanding or favourable attitude towards the use of the components of the GESS. Education is considered the stake for developing favourable attitude (Milton and Mullan, 2010). More than half (52.7\%) of them had more than ten years of farming experience, which shows they have garnered an ample farming knowledge through experience and this can have influence on their attitude towards GESS. 
Creative commons User License: CC BY-NC-ND

Abstracted by: EBSCOhost, Electronic Journals Service (EJS), Google Scholar, Directory of Open Access Journals (DOAJ), Journal Seek, Scientific Commons,

Food and Agricultural Organization (FAO), CABI and Scopus
Journal of Agricultural Extension

Vol. XX (X) XXXXXX, 20XX

ISSN(e): 24086851; ISSN(Print); 1119944X

http://journal.aesonnigeria.org

http://www.ajol.info/index.php/jae

Email: editorinchief@aesonnigeria.org

Table 1: Distribution of respondents by personal characteristics

\begin{tabular}{|c|c|c|}
\hline Variables & Percentage & Mean \\
\hline \multicolumn{3}{|l|}{ Age } \\
\hline $21-30$ & 14.4 & 42.1 \\
\hline $31-40$ & 38.9 & \\
\hline $41-50$ & 28.9 & \\
\hline $51-60$ & 14.4 & \\
\hline $61-70$ & 3.3 & \\
\hline \multicolumn{3}{|l|}{ Marital status } \\
\hline Single & 0.6 & \\
\hline Married & 90.0 & \\
\hline Divorced & 0.6 & \\
\hline Widowed & 8.9 & \\
\hline \multicolumn{3}{|l|}{ Educational attainment } \\
\hline No formal education & 42.2 & \\
\hline Adult education & 2.2 & \\
\hline Primary education & 27.8 & \\
\hline Secondary education & 26.1 & \\
\hline Tertiary education & 1.7 & \\
\hline \multicolumn{3}{|l|}{ Household size } \\
\hline $1-3$ & 8.9 & 5.4 \\
\hline $4-6$ & 76.7 & \\
\hline 7-9 & 10.0 & \\
\hline 10 and above & 4.4 & \\
\hline \multicolumn{3}{|l|}{ Religion } \\
\hline Christianity & 50.6 & \\
\hline Islam & 49.4 & \\
\hline \multicolumn{3}{|l|}{ Secondary occupation } \\
\hline Trading & 70.6 & \\
\hline Artisan & 5.0 & \\
\hline Processing agric products & 24.4 & \\
\hline \multicolumn{3}{|l|}{ Farming experience } \\
\hline $1-10$ & 47.2 & 14.8 \\
\hline $11-20$ & 33.3 & \\
\hline $21-30$ & 13.3 & \\
\hline $31-40$ & 6.1 & \\
\hline
\end{tabular}

Source: Field survey, 2015.

\section{Sources of information}

Friends $(\bar{x}=1.89)$ and relatives $(\bar{x}=1.69)$ ranked $1^{\text {st }}$ and $3^{\text {rd }}$ respectively on the order of preference for sourcing information by the cassava women farmers on GESS. This shows that rural farmers rely on their friends, relatives and neighbours for information. Radio $(\bar{x}=1.74)$ ranked $2^{\text {nd }}$. This emphasizes the values and 
Creative commons User License: CC BY-NC-ND

Abstracted by: EBSCOhost, Electronic Journals Service (EJS),

Google Scholar, Directory of Open Access Journals (DOAJ),

Journal Seek, Scientific Commons

Food and Agricultural Organization (FAO), CABI and Scopus
Journal of Agricultural Extension

Vol. XX (X) XXXXXX, 20XX

ISSN(e): 24086851; ISSN(Print); 1119944X

http://journal.aesonnigeria.org

http://www.ajol.info/index.php/jae

Email: editorinchief@aesonnigeria.org

importance of radio as source information to farmers in rural areas (Fadiji, Atala and Voh, 2005).

Table 2: Distribution of respondents by sources of information on GESS

\begin{tabular}{lll}
\hline Information sources & Mean & Rank \\
\hline Friends & 1.89 & $1^{\text {st }}$ \\
Radio & 1.74 & $2^{\text {nd }}$ \\
Relatives & 1.69 & $3^{\text {rd }}$ \\
Cooperative society & 1.08 & $4^{\text {th }}$ \\
Extension agents & 0.98 & $5^{\text {th }}$ \\
Television & 0.96 & $6^{\text {th }}$ \\
Bill boards & 0.61 & $7^{\text {th }}$ \\
Posters & 0.59 & $8^{\text {th }}$ \\
Newspapers & 0.50 & $9^{\text {th }}$ \\
Magazines & 0.22 & $10^{\text {th }}$ \\
\hline
\end{tabular}

Source: Field survey, 2015.

\section{Sources of inputs}

Availability, affordability and accessibility are three key factors that usually determine extent of patronage, and since agricultural practices are time bound, getting the right input at the right time is very vital to the success of agricultural activities. Open market ranked first among the sources of agricultural inputs available to the respondents $(\bar{x}=1.98)$. Olaleye, Ibrahim and Ojo (2009) observed that farmers source agricultural inputs such as fertilizers, improved seeds and others from the open market. Giving that the respondents were registered farmers in the GESS, with the benefit of obtaining subsidized and unadulterated inputs, one would have expected they procure inputs provided by the scheme thus making the source rank high. However, findings showed that the GESS redemption centres $(\bar{x}=0.50)$ was the penultimate source of input procurement. A reason for this, according to Fadairo, Olutegbe and Tijani (2015), is that the bureaucratic bottlenecks at the redemption centres always resulted in long queues which usually frustrate the farmers. They opined that the proximity to the redemption centres also pose a serious challenge to the farmers. Extension agents $(\bar{x}=0.03)$ ranked last, this gives an indication of the ineffectiveness of the Nigerian extension system. 
Creative commons User License: CC BY-NC-ND

Abstracted by: EBSCOhost, Electronic Journals Service (EJS),

Google Scholar, Directory of Open Access Journals (DOAJ),

Journal Seek, Scientific Commons,

Food and Agricultural Organization (FAO), CABI and Scopus
Journal of Agricultural Extension

Vol. XX (X) XXXXXX, 20XX

ISSN(e): 24086851; ISSN(Print); 1119944X

http://journal.aesonnigeria.org

http://www.ajol.info/index.php/jae

Email: editorinchief@aesonnigeria.org

Table 3: Distribution of respondents by sources of input procurement

\begin{tabular}{lll}
\hline Information sources & Mean & Rank \\
\hline Open market & 1.89 & $1^{\text {st }}$ \\
Middlemen & 1.78 & $2^{\text {nd }}$ \\
Cooperative society & 1.66 & $3^{\text {rd }}$ \\
Government institutions & 1.01 & $4^{\text {th }}$ \\
GESS redemption centre & 0.50 & $5^{\text {th }}$ \\
Extension agents & 0.03 & $6^{\text {th }}$ \\
\hline
\end{tabular}

Source: Field survey, 2015.

\section{Attitude towards components of GESS}

Table 3 reveals that $63.3 \%$ of the respondents had favourable attitude towards the components of GESS as against $36.7 \%$ who had unfavourable attitude. This favourable inclination of the respondents infers they consider GESS a viable means of enhancing the productivity of farmers. There is the need for GESS organizers to harness the respondents' enthusiasm by intensifying the activities of the various components of the scheme the result of which would translate to increase in agricultural production thus ensuring food security for the nation.

Table 4: Distribution of respondents by attitude towards components of GESS

\begin{tabular}{llllll}
\hline Category & Percentage & Maximum & Minimum & Mean & SD \\
\hline Favourable & 63.3 & 130 & 89 & 119.19 & 8.61 \\
$\begin{array}{l}(119-130) \\
\text { Unfavourable }\end{array}$ & 36.7 & & & & \\
(89-118) & & & & & \\
\hline & Source: Field survey, 2015. & & & &
\end{tabular}

Source: Field survey, 2015.

\section{Participation in GESS}

The respondents' level of participation in GESS shows that majority (68.3\%) had high participation, while $31.7 \%$ had low participation. The high participation level exhibited by the majority of them could be attributed to their favourable attitude 
Creative commons User License: CC BY-NC-ND

Abstracted by: EBSCOhost, Electronic Journals Service (EJS),

Google Scholar, Directory of Open Access Journals (DOAJ),

Journal Seek, Scientific Commons,

Food and Agricultural Organization (FAO), CABI and Scopus
Journal of Agricultural Extension

Vol. XX (X) XXXXXX, 20XX

ISSN(e): 24086851; ISSN(Print); 1119944X

http://journal.aesonnigeria.org

http://www.ajol.info/index.php/jae

Email: editorinchief@aesonnigeria.org

towards the scheme. A significant correlation has been observed between attitude and motivation towards a chosen profession (Al-Rawahi and Al-Yarabi, 2013).

Table 5: Distribution of respondents by level of participation in GESS

\begin{tabular}{llllll}
\hline Category & Percentage & Maximum & Minimum & Mean & SD \\
\hline High & 68.3 & 22 & 1 & 14.4 & 4.0 \\
$(14-22)$ & & & & & \\
Low & 31.7 & & & & \\
$(1-13)$ & & & & \\
\hline
\end{tabular}

Source: Field survey, 2015.

\section{Constraints to participation in GESS}

As indicated in Table 6 , inadequate finance $(\bar{x}=1.94)$ and high illiteracy amongst women farmers $\left(\bar{x}=1.93\right.$ ranked $1^{\text {st }}$ and $2^{\text {nd }}$ among the constraints to participation in the GESS). These findings corroborate a report that women constitute nearly $70 \%$ of the world's poor and 65\% of the world's illiterate (This Day Newspaper, 2010). Access to finance is a challenge to women, especially rural women (Hiscox and Goldstein, 2014). Gender inequality $(\bar{x}=1.88)$ ranked $3^{\text {rd }}$, as there are occasions of gender differences against women which are evident in property right, control over resources, access to inputs and services (Croppenstedt, Goldstein, and Rosas, 2013). Complexity of registration process $(\bar{x}=0.48)$ and too many middlemen $(\bar{x}=$ 0.44) were not regarded as serious constraints to participation in GESS as they ranked $13^{\text {th }}$ and $14^{\text {th }}$ respectively. 
Creative commons User License: CC BY-NC-ND

Abstracted by: EBSCOhost, Electronic Journals Service (EJS),

Google Scholar, Directory of Open Access Journals (DOAJ),

Journal Seek, Scientific Commons,

Food and Agricultural Organization (FAO), CABI and Scopus
Journal of Agricultural Extension

Vol. XX (X) XXXXXX, 20XX

ISSN(e): 24086851; ISSN(Print); 1119944X

http://journal.aesonnigeria.org

http://www.ajol.info/index.php/jae

Email: editorinchief@aesonnigeria.org

Table 6: Distribution of respondents by constraints to participation in GESS

\begin{tabular}{lll}
\hline Constraints & Mean & Rank \\
\hline Inadequate finance & 1.94 & $1^{\text {st }}$ \\
High level of illiteracy amongst farmers & 1.93 & $2^{\text {nd }}$ \\
Gender inequality & 1.88 & $3^{\text {rd }}$ \\
High cost of production & 1.79 & $4^{\text {th }}$ \\
Inadequate information on GESS & 1.79 & $4^{\text {th }}$ \\
Access to land & 1.41 & $6^{\text {th }}$ \\
Poor policy formulation and implementation & 1.07 & $7^{\text {th }}$ \\
Poor soil fertility & 1.05 & $8^{\text {th }}$ \\
Lack of technical support & 0.90 & $9^{\text {th }}$ \\
High cost of improved seeds & 0.77 & $10^{\text {th }}$ \\
Bureaucratic bottleneck & 0.59 & $11^{\text {th }}$ \\
Lack of skilled labour & 0.52 & $12^{\text {th }}$ \\
Registration complexity & 0.48 & $13^{\text {th }}$ \\
Too many middlemen & 0.44 & $14^{\text {th }}$ \\
\hline
\end{tabular}

Source: Field survey, 2015

\section{Relationship between respondents' selected personal characteristics and attitude towards GESS}

The level of education had significant positive relationship with the farmers attitude towards GESS $\left(x^{2}=2.315, p=0.040\right)$. It informs that the respondents' educational status can determine their attitude towards the scheme. Okwoche, Asogwa and Obinne, (2012\} observed that education is crucial to one's disposition towards any change programme. Also, significant relationship was observed between farming experience and farmers' attitude towards GESS $(r=0.267, p=0.000)$. It indicates that the number of years a cassava farmer is involved in farming is capable of influencing her attitude towards GESS. This can be seen from the aspect that farmers with more farming experience can take more risk than those with less experience. This risk bearing ability might have increased the respondents' response towards GESS. 
Creative commons User License: CC BY-NC-ND

Abstracted by: EBSCOhost, Electronic Journals Service (EJS),

Google Scholar, Directory of Open Access Journals (DOAJ),

Journal Seek, Scientific Commons,

Food and Agricultural Organization (FAO), CABI and Scopus
Journal of Agricultural Extension

Vol. XX (X) XXXXXX, 20XX

ISSN(e): 24086851; ISSN(Print); 1119944X

http://journal.aesonnigeria.org

http://www.ajol.info/index.php/jae

Email: editorinchief@aesonnigeria.org

Table 7: Relationship between personal characteristics and attitude towards GESS

\begin{tabular}{lll}
\hline Variable & $\mathbf{X}^{2}$ & Df \\
\hline Marital status & 2.315 & 3 \\
Education & $5.494^{*}$ & 4 \\
& r-value & \\
Age & 0.009 & - \\
Household size & 0.065 & - \\
Farming Exper & $0.267^{*}$ & - \\
\hline
\end{tabular}

${ }^{\star} P \leq 0.05$. Source: Field survey, 2015

Relationship between participation, input source, constraints and attitude towards GESS

A significant correlation was observed between sources of inputs and attitude towards GESS $(r=0.223, p=0.003)$. It suggests that when inputs are accessible to farmers, there is likelihood for them to become favourably disposed towards GESS because inputs can help to boost agricultural productivity.

Respondents' level of participation and their attitude towards GESS were significantly correlated $(r=0.258, p=0.000)$. It follows that how well farmers participate in GESS hinges on their disposition (favourably or unfavourably) towards the scheme. This finding is consistent with Botlhoko and Oladele (2013) who posited that farmers' participation in agricultural schemes increases if they have a favourable disposition towards such schemes.

Constraint faced by the respondents also had a significantly correlation with attitude towards GESS ( $r=-0.424, p=0.000)$. The correlation coefficient is consistent with expectation in that when the respondents encounter constraints, they develop an unfavourable disposition towards GESS. The more the constraints the unfavourable the attitude and vice versa This finding agrees with Nweke (2002) that constraints faced by farmers affect the adoption of agricultural innovation. 
Creative commons User License: CC BY-NC-ND

Abstracted by: EBSCOhost, Electronic Journals Service (EJS),

Google Scholar, Directory of Open Access Journals (DOAJ),

Journal Seek, Scientific Commons,

Food and Agricultural Organization (FAO), CABI and Scopus
Journal of Agricultural Extension

Vol. XX (X) XXXXXX, 20XX

ISSN(e): 24086851; ISSN(Print); 1119944X

http://journal.aesonnigeria.org

http://www.ajol.info/index.php/jae

Email: editorinchief@aesonnigeria.org

Table 8: Correlations between participation, input source, constraints and attitude towards GESS

\begin{tabular}{ll}
\hline Variable & $\mathbf{r}-$ value \\
\hline Input source & $0.223^{*}$ \\
Participation & $0.258^{*}$ \\
Constraints & $-0.424^{*}$ \\
\hline
\end{tabular}

$\mathrm{P} \leq 0.05$.Source: Field survey, 2015

\section{Conclusion and Recommendations}

The majority of women cassava farmers had favourable attitude towards the GESS, though they were unable to access agricultural inputs from the redemption centers due to some factors ranging from illiteracy, gender inequality and corruption. Educational qualification, farming experience, participation, input source and constraints were significant predictors of respondents' attitude towards GESS. Registered association/groups should be used for the proper distribution of inputs in order to eliminate diversion. Credit facilities should be made available and accessible to women cassava farmers through various financial institutions with not more than $5 \%$ interest rate and identification by their registered association(s) i.e registered association that they belong to as a member should be used as collateral.

\section{References}

Akinbile, L. A. (2007). Social impact of limestone exploration in Yewa North Local Government Area of Ogun State, Nigeria: Pakistan journal of social science 1: 107-111

Al-Rawahi, N. and Al-Yarabi, A. (2013) The Relationship between Attitudes

Toward Participation in Physical Activities and Motives for Choosing Teaching Physical Education as a Career: International Journal of Instruction, Vol.6, No.2.

Botlhoko, C. J. and Oladele, O. I. (2013) Factors affecting farmers participation in agricultural projects in NgakaModiriMolema District North West Province, South Africa: Journal of Human Ecology, 41(3): 201-206.

Croppenstedt, A., Goldstein, M. and Rosas, N. (2013) Gender and Agriculture: Inefficiencies, Segregation, and Low Productivity Traps World Bank, Washington, DC. (C) World Bank. 
Creative commons User License: CC BY-NC-ND

Abstracted by: EBSCOhost, Electronic Journals Service (EJS),

Google Scholar, Directory of Open Access Journals (DOAJ),

Journal Seek, Scientific Commons,

Food and Agricultural Organization (FAO), CABI and Scopus
Journal of Agricultural Extension

Vol. XX (X) XXXXXX, 20XX

ISSN(e): 24086851; ISSN(Print); 1119944X

http://journal.aesonnigeria.org

http://www.ajol.info/index.php/jae

Email: editorinchief@aesonnigeria.org

Enitan, F. O. (2010). Influence of Socio-economic Characteristics on Use of Modern Cassava Processing Technologies among Women Processors in Ogun State, Nigeria. Journal of Social Science; 24(1): 43-50.

Fadiji, T. O., Atala, T. K. and Voh, J. P. (2005) Sources and uses of Extension Information among Maize Farmers in Rural Northern Nigeria: Journal of Agriculture and Social Research, vol. 5 (1), pages 11-17.

Fabiyi, E.F, Danladi, B. B., Akande, K. E. and Mahmood, Y. (2007) Role of women in agricultural development and their constraints: a case study of Biliri Local Government Area, Gombe State, Nigeria.Pakistan Journal of Nutrition 6(6): 676-680. http://pibs.org/pinonline/fin770.pdf

Fadairo, O. S., Olutegbe, N. S. and Tijani, A. M. (2015) .Attitude of crop farmers towards e-wallet platform of the Growth Enhancement Support Scheme for input delivery in Oke Ogun area of Oyo state: Journal of Agricultural Informatics, 2015 Vol. 6, No. 2.

FMARD, (2013) Agricultural transformation agenda support program - phase

1 (ATASP-1):Strategic environmental and social assessment (SESA) executive summary; OSAN Division: OSAN.2 Project Number: P-NGAAB-003

FAO, (2012) .Agricultural Statistics: Food and Agricultural Organization of United Nations. Rome. http://www.faostat.fao.orgHiscox

Koyenikan, M. J. and Edeoghon, C. O. (2010). Gender desegregation of the activities of cassava processing group in southeast ecological zone of Nigeria. Nigerian Journal of Rural Sociology, vol. 11(1) pp. 95-103.

Lawanson, O. I. (2008). Female labour force participation in Nigeria:

Determinants and Trends. Oxford Business and Economic Conference Program, Oxford United Kingdom.

Milton, A. and Mullan, B. (2010). Consumer food safety education for the domestic environment: A systematic Review. British Food Journal

Obiora, C. (2013). Need assessment: Overview from women farmers in Anambra State, Nigeria. Greener Journal of Agricultural Sciences; vol. 3 (8), pp. 618-622.

Ogbonna, K.I. and Okoroafor E. (2004). Enhancing the capacity of women for increased participation in Nigeria main-streaming agriculture: a re-designing of strategies. Paper prepared for presentation at the Farm Management Association of Nigeria Conference, Abuja, Nigeria

Okwoche, V. A., Asogwa, B. C. and Obinne, P.C. (2012). Evaluation of Agricultural Credit Utilization by Cooperative Farmers in Benue State of Nigeria. European Journal of Economics, Finance and Administration Science.Vol. 47, pp. 18 27.

Olaleye, R.S, M Ibrahim, M.A Ojo (2009). Probit Analysis of Women's 
Creative commons User License: CC BY-NC-ND

Abstracted by: EBSCOhost, Electronic Journals Service (EJS),

Google Scholar, Directory of Open Access Journals (DOAJ),

Journal Seek, Scientific Commons,

Food and Agricultural Organization (FAO), CABI and Scopus
Journal of Agricultural Extension

Vol. XX (X) XXXXXX, 20XX

ISSN(e): 24086851; ISSN(Print); 1119944X

http://journal.aesonnigeria.org

http://www.ajol.info/index.php/jae

Email: editorinchief@aesonnigeria.org

Access to Agricultural Inputs in Bosso Local Government Area, Niger State, Nigeria Journal of Agricultural Extension. Vol. 13, No 2. African journal online AJOL

Nweke, F. I., Lynam, J. K., and Spencer, D. S. C. (2002). The cassava transformation: Africa's best-kept secret. East Lansing: Michigan State University Press.

Porter, Raewyn.,Zovighian, Diane (2014). Unpacking performance and empowerment in female farmers' groups: the case of the Fadama project in Nigeria. Perspectives on social development.Washington, DC: World Bank Group.

This Day Newspaper (5th October, 2010). Nigeria: combating illiteracy among women. http://this day live.com

World Bank (2014). Leveling the field: improving opportunities for women farmers in Africa (Vol. 2): Executive summary (English). 